\title{
A redescription of Arostrilepis beringiensis (Kontrimavichus et Smirnova, 1991) and descriptions of two new species from Palaearctic microtine rodents, Arostrilepis intermedia sp. $\mathbf{n}$. and $A$. janickii sp. n. (Cestoda: Hymenolepididae)
}

\author{
Arseny A. Makarikov ${ }^{1,2}$ and Vytautas L. Kontrimavichus ${ }^{1}$ \\ ${ }^{1}$ Institute of Ecology of Nature Research Centre, Akademijos 2, Vilnius 08412, Lithuania; \\ ${ }^{2}$ Institute of Systematics and Ecology of Animals, Siberian Branch, Russian Academy of Sciences, Frunze Str. 11, \\ 630091 Novosibirsk, Russia
}

\begin{abstract}
Arostrilepis beringiensis (Kontrimavichus et Smirnova, 1991) is redescribed on the basis of its type specimens from Lemmus trimucronatus (Richardson) and material from the collections of the Institute of Systematics and Ecology of Animals, Novosibirsk from the lemmings Myopus schisticolor (Lilljeborg) and Lemmus sibiricus (Kerr) from the Asian part of Russia. Specimens previously identified as Arostrilepis horrida (Linstow, 1901) from voles are revised and newly collected materials are addressed. Two new species of the genus Arostrilepis Mas-Coma et Tenora, 1997, A. intermedia sp. n. from red-backed voles (Myodes Pallas) from the Asian part of Russia and A. janickii sp. n. from Europe, are described. These species are clearly distinguished from congeners by form and size of the cirrus and its armature as well as the type of arrangement for the testes, position of the cirrus-sac with regard to poral ventral osmoregulatory canals, and host specificity.
\end{abstract}

Keywords: Cestoda, Hymenolepididae, Arostrilepis beringiensis, redescription, Arostrilepis intermedia, Arostrilepis janickii, new species, morphology, microtine rodents

Previous studies have suggested that the type species of the genus Arostrilepis Mas-Coma et Tenora, 1997, A. horrida (Linstow, 1901), which has a presumed Holarctic distribution, represents a complex of cryptic species (Johri 1956, Mas-Coma et al. 1980, Kontrimavichus and Smirnova 1991, Gulyaev and Chechulin 1997, MasComa and Tenora 1997, Asakawa et al. 2002, Hoberg et al. 2003, Cook et al. 2005, Hwang et al. 2007, Haukisalmi et al. 2009, 2010, Makarikov et al. 2011). But for most of the last century, $A$. horrida was considered to represent a single, widespread (geographically and with respect to microtine hosts), and hyper-variable species. Comparative studies by Rausch (1952), Schiller (1952), Voge (1952), Murai and Tenora (1973), Egorova and Nadtochii (1975) and others failed to recognize species limits based on structural characters (some reasons for this are outlined in Hoberg et al. 2003). A re-examination of the type series revealed that data for host range and geographical distribution of $A$. horrida (sensu stricto) are limited to those reported in the original description (Makarikov et al. 2011). Consequently, there are still unresolved questions regarding this species (i.e., morphology of gravid proglottides and validity of the type host). Thus, there is an urgent need to locate other specimens of this species and to expand upon its original description and redescription (Makarikov et al. 2011).

In the course of examining diversity within the $A$. horrida complex, four additional species were reported in the genus Arostrilepis. These were A. beringiensis (Kontrimavichus et Smirnova, 1991) Gulyaev et Chechulin, 1997 from the lemming Lemmus sibiricus (Kerr) in Chukotka (Kontrimavichus and Smirnova 1991), A. microtis Gulyaev et Chechulin, 1997 from voles of the genera Microtus Schrank and Arvicola Lacépède from the Altai Mts. and Western Siberia (Gulyaev and Chechulin 1997), A. macrocirrosa Makarikov, Gulyaev et Kontrimavichus, 2011 and A. tenuicirrosa Makarikov, Gulyaev et Kontrimavichus, 2011 from red-backed voles (Myodes Pallas) from the Asian part of Russia (Makarikov et al. 2011).

Hoberg et al. (2003) and Cook et al. (2005) across Beringia recognised 10 distinct genetic lineages of Arostrilepis among various genera of the Microtinae, which they considered to be distinct species. From their standpoint, the genus Arostrilepis represents a poorly investigated and widespread complex of cryptic species. Molecular 
sequence data and a limited range of structural characters were strongly correlated, demonstrating a considerable level of species diversity in the genus (K.E. Galbreath, E.P. Hoberg and J.A. Cook; unpublished data). This conclusion is consistent with recent descriptions of new species of Arostrilepis (Makarikov et al. 2011) and results presented in our current study.

Building on our recent comparative studies of cestode species diversity, we now recognize two additional species of the genus Arostrilepis. One species was found in red-backed voles: Myodes rutilus (Pallas) and M. rufocanus (Sundevall) from Sakhalin Island. We also found some conspecific specimens from microtine rodents from the Asian part of Russia, misidentified as A. horrida, in the collection of the Institute of Systematics and Ecology of Animals, Novosibirsk (ISEZH). The other new species was found during examination of collections of hymenolepidid cestodes at the Natural History Museum, Geneva, Switzerland (MHNG), among specimens misidentified as $A$. horrida, as a parasite of European voles of the genera Arvicola, Microtus and Chionomys Miller.

Comparative studies of these two new species and their congeners revealed new details of the morphology of $A$. beringiensis, which resulted in its redescription. In the present paper, we provide a redescription of $A$. beringiensis based on its type specimens and additional materials held in the ISEZH. Further, we describe two previously unrecognized species of the genus Arostrilepis circulating in microtine rodents from the Palaearctic.

\section{MATERIALS AND METHODS}

Cestodes from rodents were collected during June 2005 in the Poronayskiy Reserve, near the town of Poronaysk on Sakhalin Island. Two species of Myodes were sampled: M. rutilus (Pallas) (17 specimens), M. rufocanus (Sundevall) (37 specimens). Host specimens were dissected immediately after their death. Cestodes were isolated, washed and relaxed in water; they were then fixed in $70 \%$ ethanol. They were stained with Ehrlich's haematoxylin, differentiated in a $3 \%$ aqueous solution of ferricammonium sulphate 12-hydrate, dehydrated in an ethanol series, cleared in clove oil and mounted in Canada balsam. Some specimens were mounted in Berlese's medium to facilitate the examination of their copulatory apparatus. The type specimens of the two new species were deposited into the collections of the Zoological Museum at the Institute of Systematics and Ecology of Animals, Novosibirsk (ISEZH), the Natural History Museum, Geneva, Switzerland (MHNG) and the Institute of Parasitology, Academy of Sciences of the Czech Republic, České Budějovice, Czech Republic (IPCAS).

The following type materials from previously described species were studied: a syntype of $A$. horrida, No. 3640-Q, Museum für Naturkunde, Berlin, Germany, loaned by Dr. Birger Neuhaus; A. beringiensis, holotype GELAN No. 646 and paratype GELAN No. 647, Centre of Parasitology of the A.N. Severtsov Institute of Ecology and Evolution, of the Russian Academy of Sciences, Moscow, Russia (GELAN); A. microtis, No. C 751 (holotype) and No. C 752-761 (paratypes), Zoological Museum of ISEZH, Novosibirsk, Russia.

Other materials examined by us included tapeworms from the collections of ISEZH, representing more than 650 slides of specimens of Arostrilepis from microtine rodents from the Altai Mts., Siberia and the Russian Far East. Additionally, specimens originally identified as $A$. horrida from voles from France and Switzerland and deposited in MHNG were also examined in the course of the present study.

Measurements are given in micrometres except where otherwise stated. Metrical data for the holotypes are followed by those for paratypes in parentheses.

\section{RESULTS}

Arostrilepis beringiensis (Kontrimavichus et Smirnova, 1991) Gulyaev et Chechulin, 1997

Figs. 1, 2

Redescription (based on holotype GELAN No. 646, paratype GELAN No. 647 and three specimens from Lemmus sibiricus and Myopus schisticolor from Yakutia and Khabarovskiy Kray, Russia): Fully developed strobila 100-125 mm long, with maximum width at pregravid or gravid proglottides, 1.4-1.6 mm. Strobila flat, consisting of 610-900 craspedote proglottides. Scolex slightly compressed dorso-ventrally, 320 (230-260) wide, clearly wider than neck. Suckers unarmed, ovoid in surface view, 250-270 × 140-153 (170-235 × 120-160), prominent, with thick walls (Fig. 1A, B). Rhynchus and rostellar apparatus absent. Neck relatively long and narrow, 210 (160-200) wide.

Two pairs of osmoregulatory canals, without transverse anastomoses. Dorsal osmoregulatory canals thin, 2-3.5 (1-3) wide, situated predominantly in same sagittal plane as ventral canals. Ventral osmoregulatory canals 50-75 (40-120) wide. Position of dorsal osmoregulatory canals not always constant; their loops may be situated laterally to ventral canals. Genital pores unilateral, dextral. Genital ducts may pass dorsally or between longitudinal osmoregulatory canals within the same strobila; intersegmental variation does not show any regularity (Fig. 1C, D). Development of proglottides gradual, protandrous. Strobilar part containing juvenile proglottides without external segmentation; proglottides become externally distinct at level of premature part of strobila.

Mature proglottides 240-280 × 880-1010 (200-276 × 750-1200), transversely elongate, trapeziform (Fig. 1C, D). Testes relatively large, usually three in number, almost of equal size, $160-185 \times 120-142(100-180 \times 80-140)$, round or oval, commonly situated in triangle with flat angle or rarely, testes form one row; poral testis separated from two antiporal testes by female gonads. Arrangement of testes may vary. Cirrus-sac relatively short, 125-140 $\times$ 27-35 (95-135 × 25-36), with well-developed external muscular layers. Antiporal part of cirrus-sac commonly does not reach ventral longitudinal canal (Figs. 1D, 2C). 

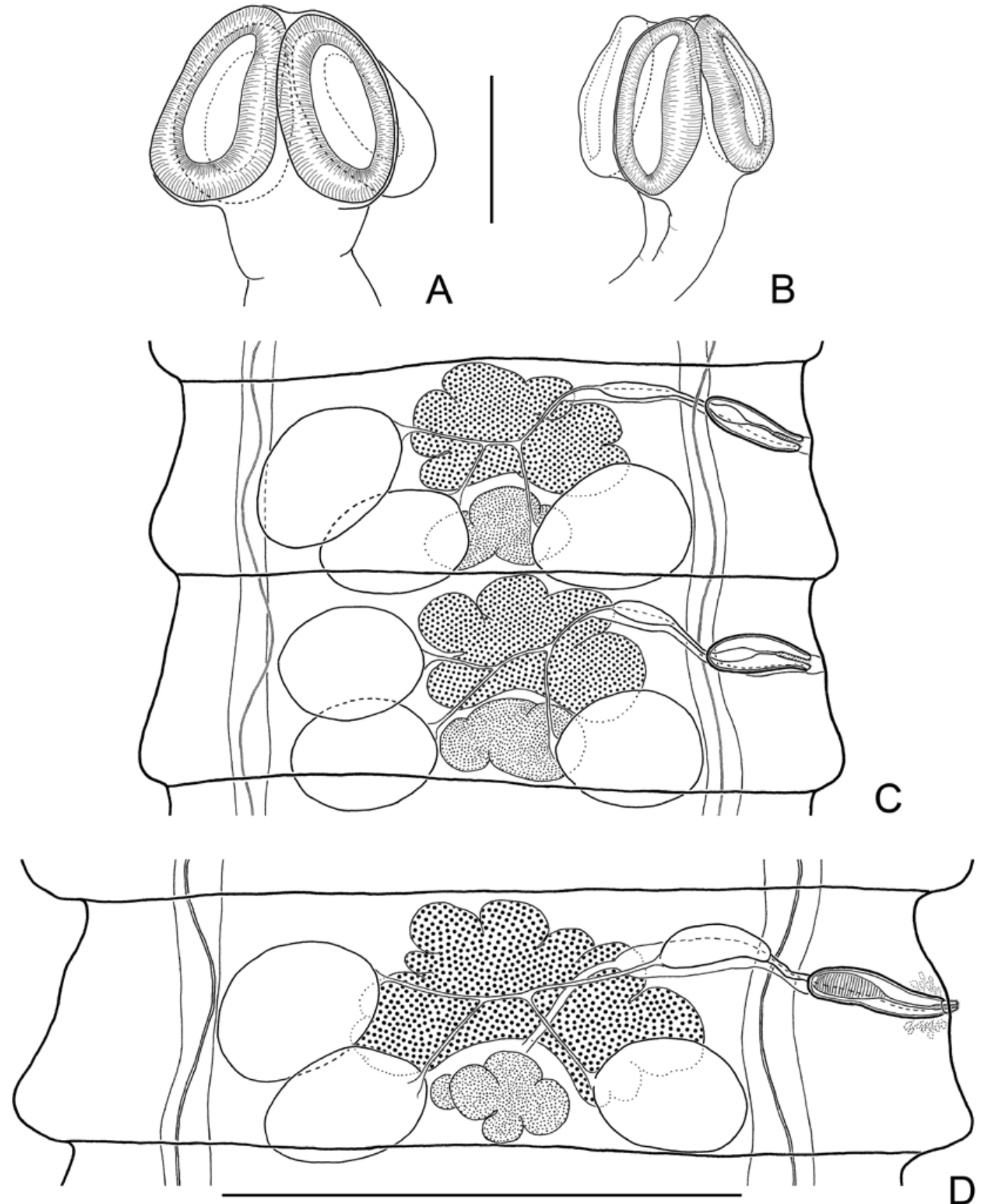

Fig. 1. Arostrilepis beringiensis (Kontrimavichus et Smirnova, 1991). A-holotype, dorso-ventral view of scolex; B-paratype, sublateral view of scolex; $\mathbf{C}$ - holotype, male mature proglottides; $\mathbf{D}$-holotype, hermaphroditic mature proglottis. Scale bars: $A, B=200 \mu \mathrm{m} ; \mathrm{C}, \mathrm{D}=500 \mu \mathrm{m}$.

Genital atrium simple, cup-shaped, deep, opens laterally about middle of lateral proglottis margin. Cirrus small, 37-42 × 11-12 (33-44 × 10-12), cylindrical, armed along its entire length with relatively small (up to 2.2-2.7 long) rosethorn-shaped spines (Fig. 2A). Internal seminal vesicle with circular musculature, ovoid, 54-70 × 22-30 (50$70 \times 20-27$ ), shorter than half of cirrus-sac length (Figs. 1D, 2C). External seminal vesicle transversely elongate, 105-135 × 40-55 (130-180 × 40-75), clearly outlined from vas deferens, with size approximately equal to that of seminal receptacle.

Ovary 350-380 (280-380) wide, median, fan-shaped, irregularly lobed, ventral to male genital organs, occupying substantial part of median field, overlapping testes (Fig. 1D). Vitellarium 76-85 × 160-180 (60-100 × 130$170)$, postovarian, median, scarcely lobed. Vagina tubular, clearly distinct from seminal receptacle; ventral to cirrussac. Copulatory part of vagina 57-74 × 7-13 $(55-84 \times$ 

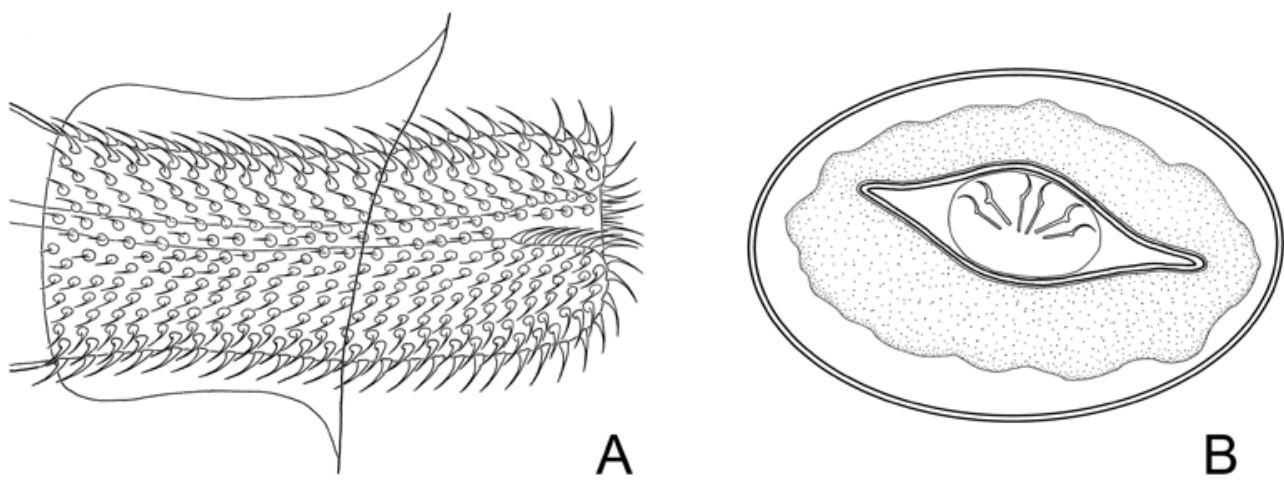

A

B
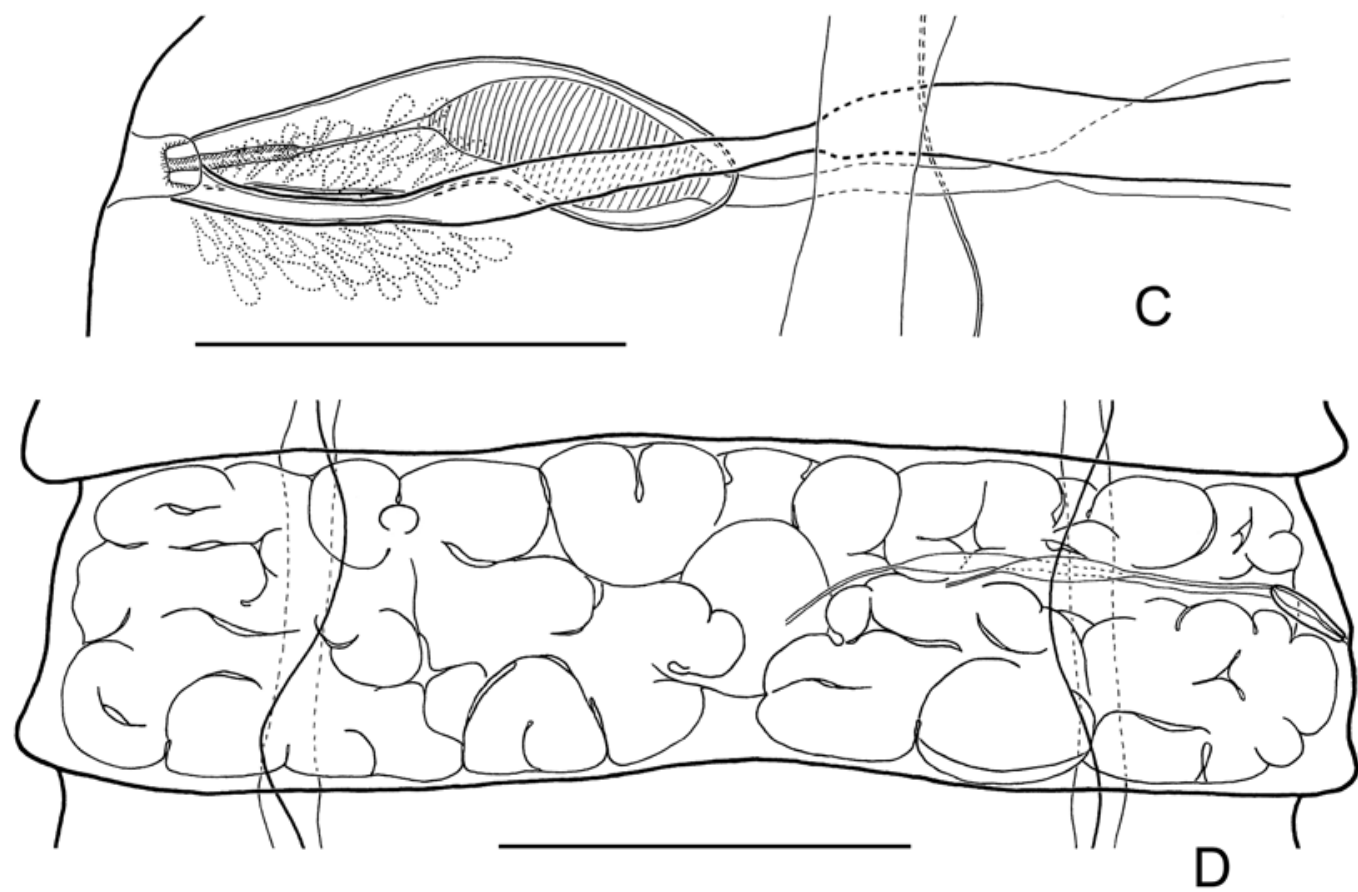

Fig. 2. Arostrilepis beringiensis (Kontrimavichus et Smirnova, 1991). A-holotype, cirrus; B - egg (No. 9452 ex Lemmus sibiricus); C - holotype, copulatory part of vagina; D - gravid proglottis (No. 9452 ex Lemmus sibiricus). Scale bars: A, B = $20 \mu \mathrm{m}$; $\mathrm{C}=100 \mu \mathrm{m} ; \mathrm{D}=500 \mu \mathrm{m}$.

8-22), thick-walled, covered externally by dense layer of small intensely stained cells; poral part of vagina infundibular (Fig. 2C). Conductive part of vagina 90-117 $\times 11-17(110-160 \times 10-20)$, thin-walled, vastly varying in diameter depending on degree of filling with sperm. Seminal receptacle relatively small, transversely elongate, $133-160 \times 34-38(100-180 \times 30-40)$.

Uterus appears as complex of fine-walled anastomosing tubes of varying length and diameter, positioned ventrally to other organs. With development of proglottides, tubular structures increase in width and uterus becomes labyrinthine. Uterus may pass dorsally or between longitudinal osmoregulatory canals within the same strobila; intersegmental variation does not show any regularity. Testes remain in postmature and pregravid proglottides; cirrus-sac and vagina persist in gravid proglottides.
Gravid proglottides transversely elongate, 300-430 × $1250-1600$. Fully developed uterus labyrinthine, occupying entire median field and extending bilaterally beyond longitudinal osmoregulatory canals (Fig. 2D). Uterus with numerous (up to 1500) small eggs. Eggs 30-36 $\times$ 48-56, elliptic, with thin outer coat (Fig. 2B); oncosphere 8-10 × 13-15. Embryophore fusiform, 10-14 × 31-36, with straight polar processes. Embryonic hooks small, 5-5.7 long.

Ty pe host: Lemmus trimucronatus (Richardson) (Rodentia: Cricetidae).

Other hosts: Myopus schisticolor (Lilljeborg), Lemmus sibiricus (Kerr).

Type locality: Chaun Lowland, Northwestern Chukotka, Russia. 
O the r localities (from the collection of ISEZH): SredneKolymskiy Rayon, Indigirka River, Yakutia; Nyukzha River, Amurskaya Oblast'; Amgun' River, Khabarovskiy Kray, Russia.

Type material: Holotype No. 646, 10.07.1979, paratype No. 647, 25.06.1976, from GELAN. The type material of A. beringiensis is represented by two slides (holotype and paratype). On each slide, one immature specimen is mounted (both without gravid proglottides). Scolex of the holotype was mounted in Berlese's medium, which affected its measurements, making them slightly larger than observed in other specimens.

Other materials: No. 9452, ex L. sibiricus, SredneKolymskiy Rayon; No. 18.28.6.1, ex L. sibiricus, Indigirka River; No. 3448, ex M. schisticolor, Amgun' River. All specimens are deposited at ISEZH.

Remarks. Arostrilepis beringiensis is distinguished from congeners by the exceptionally small cylindrical cirrus armed with relatively small rosethorn-shaped spines (Fig. 7). The cirrus-sac is also shorter than that in other Arostrilepis spp. The ovary and testes are smaller relative to those in A. horrida, A. microtis and A. tenuicirrosa (see Table 2). Furthermore, this species is characterised by the arrangement of its testes either in a flat angle or in one row. In addition, the antiporal part of the cirrus-sac commonly does not reach the ventral longitudinal canal, and the polar processes of the embryophore are straight. Arostrilepis beringiensis is a specific parasite of lemmings.

\section{Arostrilepis intermedia sp. n.}

Figs. 3, 4

Description (based on 9 specimens): Fully developed strobila 115 (100-150) mm long, with maximum width at pregravid or gravid proglottides, $1.65(1.35-1.8) \mathrm{mm}$. Strobila flat, consisting of 740-800 craspedote proglottides. Scolex slightly compressed dorso-ventrally, 310 (290-320) wide, clearly wider than neck. Suckers unarmed, ovoid in surface view, $200 \times 135(200-250 \times 130$ 150), prominent, with thin walls (Fig. 3A, B). Rhynchus and rostellar apparatus absent. Neck relatively long and narrow, 160 (140-170) wide.

Two pairs of osmoregulatory canals, without transverse anastomoses. Dorsal osmoregulatory canals thin, 2-3 (2-4) wide, situated predominantly in same sagittal plane as ventral canals. Ventral osmoregulatory canals 90-130 (70-140) wide. Position of dorsal osmoregulatory canals not always constant; their loops may be situated laterally to ventral canals. Genital pores unilateral, dextral. Genital ducts may pass dorsally or between longitudinal osmoregulatory canals within the same strobila; intersegmental variation does not show any regularity (Fig. 3C, D). Development of proglottides gradual, protandrous. Strobilar part containing juvenile proglottides without external segmentation; proglottides become externally distinct at level of premature part of strobila.

Mature proglottides 170-190 × 1040-1190 (170-200 $\times$ 950-1200), transversely elongate, trapeziform (Fig. 3C,
D). Testes relatively large, usually three in number, almost of equal size, $150-190 \times 77-110(145-210 \times 70$ $140)$, oval or pear-shaped, situated in triangle; poral testis separated from two antiporal testes by female gonads. Arrangement of testes may vary. Cirrus-sac relatively short, 185-205 × 28-34 (180-210 × 28-40), with well-developed external muscular layers. Antiporal part of cirrussac reaching ventral longitudinal canal, rarely overlapping or slightly crossing it (Figs. 3D, 4C). Genital atrium simple, cup-shaped, deep, opens laterally about middle of lateral proglottis margin. Cirrus 87-97 × 15-17 (80-98 $\times$ 14-20), cylindrical, armed along its entire length with relatively large (up to 3.5-4 long) rosethorn-shaped spines (Fig. 4A). Internal seminal vesicle with circular musculature, ovoid, 80-94 × 22-30 (70-98 × 20-34), shorter than half of cirrus-sac length (Fig. 3D). External seminal vesicle transversely elongate $150-160 \times 40-50(145-175$ $\times 35-65)$, clearly outlined from vas deferens, with size approximately equal to that of seminal receptacle.

Ovary 350-420 (300-460) wide, median, fan-shaped, irregularly lobed, ventral to male genital organs, occupying substantial part of median field, overlapping testes (Fig. 3D). Vitellarium 75-85 × 155-170 (65-88 × 130 200), postovarian, median, scarcely lobed. Vagina tubular, clearly distinct from seminal receptacle; ventral to cirrussac. Copulatory part of vagina 85-96 × 16-19 (84-110 $\times$ 12-21), thick-walled, covered externally by dense layer of small intensely stained cells; poral part of vagina infundibular (Fig. 4C). Conductive part of vagina 130-160 $\times 18-30(100-160 \times 15-36)$, thin-walled, vastly varying in diameter depending on degree of filling with sperm. Seminal receptacle relatively small, transversely elongate, $120-170 \times 40-50(110-175 \times 35-65)$.

Uterus appears as complex of fine-walled anastomosing tubes of varying length and diameter, positioned ventrally to other organs. With development of proglottides, tubular structures increase in width and uterus becomes labyrinthine. Uterus may pass dorsally or between longitudinal osmoregulatory canals within the same strobila; intersegmental variation does not show any regularity; in type specimens, uterus is mostly situated between longitudinal osmoregulatory canals. Testes remain in postmature and pregravid proglottides; cirrus-sac and vagina persist in gravid proglottides. Gravid proglottides transversely elongate 330-380 × 1525-1650 (290-450 × 1350-1750). Fully developed uterus labyrinthine, occupying entire median field and extending bilaterally beyond longitudinal osmoregulatory canals (Fig. 4D). Uterus with numerous (up to 900-1400) small eggs. Eggs 36-42 × 60-65, elliptic, with thin outer coat (Fig. 4B); oncosphere 15-20 $\times$ 20-25. Embryophore fusiform, 18-22 × 42-45, with straight polar processes. Embryonic hooks small, 7.5-8.2 long.

Type host: Myodes rufocanus (Sundevall) (Rodentia: Cricetidae). 

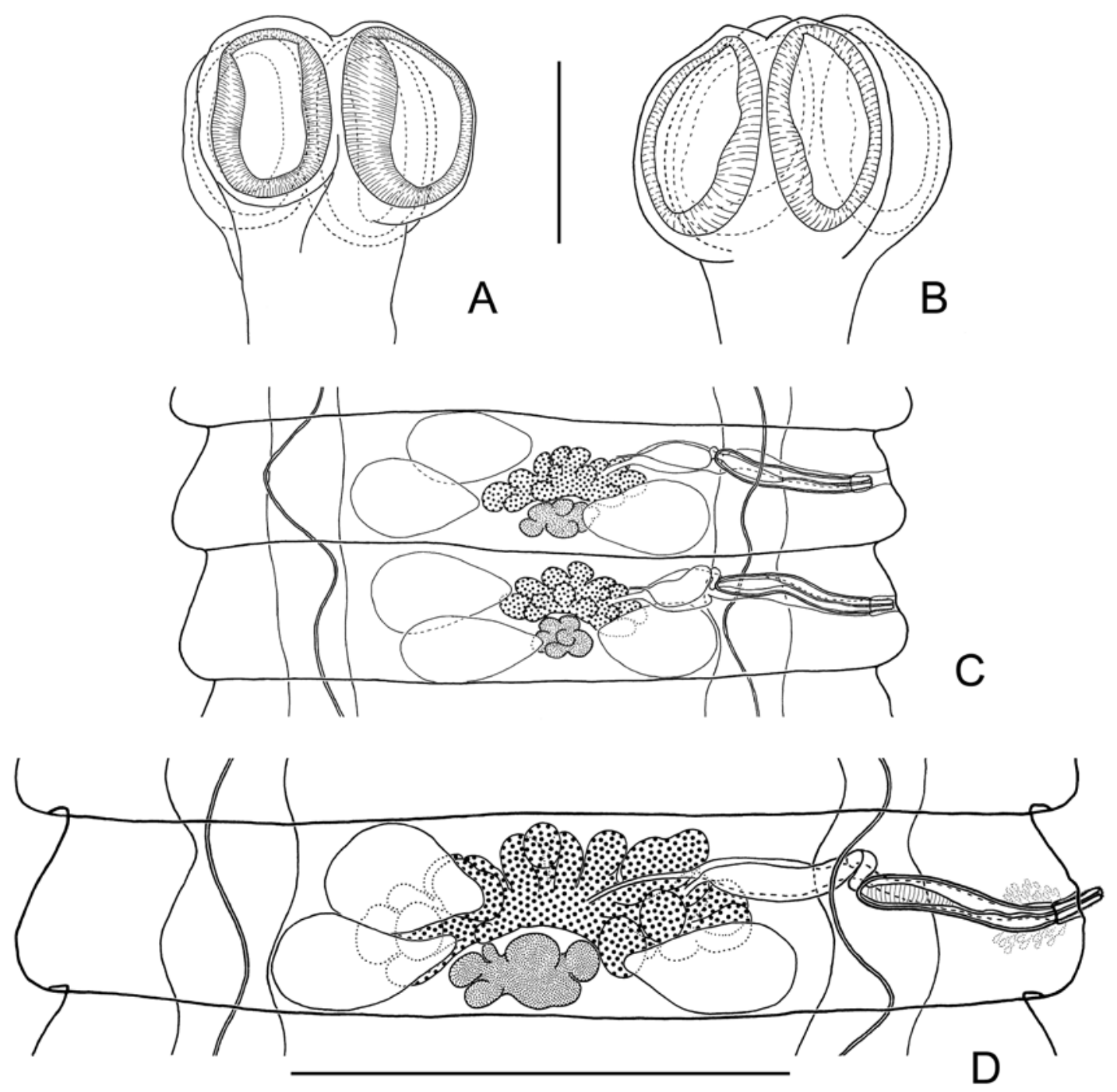

Fig. 3. Arostrilepis intermedia sp. n. A - dorso-ventral view of scolex (No. 18.28.5.13); B - sublateral view of scolex (No. 18.28.5.13); C - holotype, male mature proglottides; $\mathbf{D}$ - holotype, hermaphroditic mature proglottis. Scale bars: A, B = $200 \mu \mathrm{m} ; \mathrm{C}, \mathrm{D}=500 \mu \mathrm{m}$.

\section{Other hosts: Myodes rutilus (Pallas).}

Type locality: Poronayskiy Reserve, Sakhalin Island, Russia.

Other localities (from the collection of ISEZH): Bauntovskiy Rayon, Bol'shoy Amalot River, Republic of Buryatia, Russia; Gorniy Rayon, Sredne-Kolymskiy Rayon, Yakutia; Amgun' River, Khabarovskiy Kray, Russia.

Type material: Holotype: ISEZH No. 18.28.5.7, ex M. rufocanus, Poronayskiy Reserve, 29.07.2005 $\left(49^{\circ} 16^{\prime} \mathrm{N}\right.$, $\left.143^{\circ} 58^{\prime} \mathrm{E}\right)$. Paratypes: No. 18.28.5.8, ex M. rufocanus, 29.07.2005; No. 18.28.5.13, ex M. rufocanus, 24.07.2005; No. 18.28.5.14, ex M. rufocanus, 24.07.2005; No. 18.28.5.18, ex M. rutilus, 27.07.2005; No. 18.28.5.25, ex M. rufocanus, 29.07.2005; No. 18.28.5.30, ex M. rufocanus, 29.07.2005; INVE 78870, ex M. rufocanus, 29.07.2005. All paratypes are from the Poronayskiy Reserve $\left(49^{\circ} 16^{\prime} \mathrm{N}, 143^{\circ} 58^{\prime} \mathrm{E}\right)$, deposited in ISEZH except INVE 78870 deposited in MHNG and No. 18.28.5.13 deposited in IPCAS (Coll. No. C-607).
Ety mology: This species has been named in reference to its position between congeners, as some morphological features are in the middle of the range.

Remarks. Arostrilepis intermedia is distinguished from A. microtis, A. beringiensis, A. macrocirrosa and $A$. tenuicirrosa by the length and shape of the cirrus. In specimens of $A$. intermedia the cirrus is longer relative to those in $A$. beringiensis and A. tenuicirrosa, but smaller in comparison to $A$. macrocirrosa (Fig. 7). The cirrus is armed with relatively large rosethorn-shaped spines and has a cylindrical form; these features distinguish $A$. intermedia from A. macrocirrosa (conical cirrus), A. microtis (cirrus with wide conical basal region and a cylindrical distal region) and A. tenuicirrosa (cirrus is armed with relatively small needle-shaped spines and has a conical basal region and a very narrow cylindrical distal region). The strobila is narrower and the hermaphroditic mature proglottides are smaller than those of the syntype material 


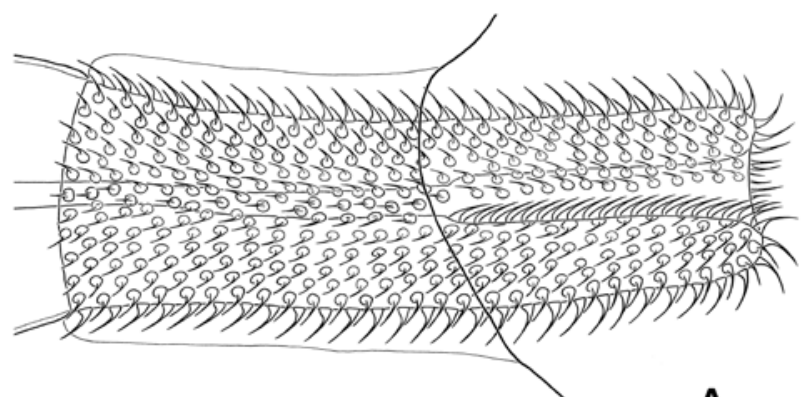

A
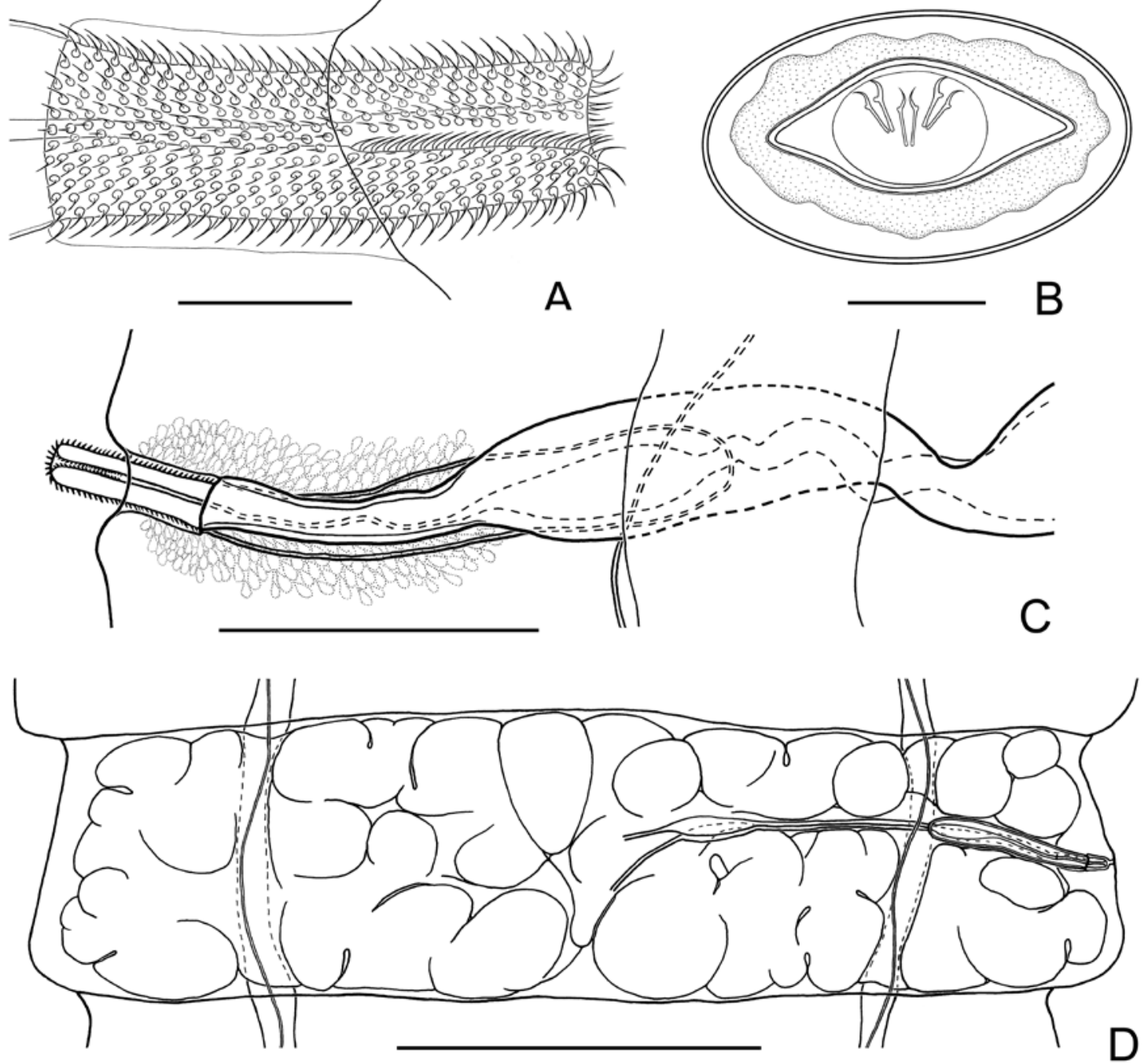

Fig. 4. Arostrilepis intermedia sp. n. A - cirrus; B - egg; C - holotype, copulatory part of vagina; D - holotype, gravid proglottis. Scale bars: A, B $=20 \mu \mathrm{m} ; \mathrm{C}=100 \mu \mathrm{m} ; \mathrm{D}=500 \mu \mathrm{m}$.

of $A$. horrida, A. microtis and A. tenuicirrosa. The cirrussac is shorter than in $A$. horrida, A. macrocirrosa, and A. microtis, but longer than in A. beringiensis. The ovary is smaller than in A. horrida and A. microtis. The egg and oncosphere are large relative to those in $A$. horrida, A. microtis and A. beringiensis (see Table 2). The antiporal end of the cirrus-sac reaches the ventral longitudinal canal but rarely overlaps it. This species can be distinguished from $A$. beringiensis as its testes are arranged in a triangle; in the latter species, the testes form a flat angle or are situated in one row. Similarly, the testes form one row in A. microtis. Furthermore, the gravid proglottides are transversely elongate and the polar processes of the embryophore are straight in $A$. intermedia. This species is a specific parasite of red-backed voles (Myodes).

\section{Arostrilepis janickii sp. n.}

Figs. 5, 6

Description (based on 15 specimens): Fully developed strobila 77 (50-80) $\mathrm{mm}$ long, with maximum width at pregravid or gravid proglottides, $1.75(1.0-2.0) \mathrm{mm}$. Flat strobila, consisting of 400-600 craspedote proglottides. Scolex slightly compressed dorso-ventrally, (190-240) wide, clearly wider than neck. Suckers unarmed, ovoid in surface view, $(110-175 \times 85-120)$, prominent, with thin walls (Fig. 5A, B). Rhynchus and rostellar apparatus absent. Neck relatively long and narrow, 112 (100-167) wide.

Two pairs of osmoregulatory canals, without transverse anastomoses. Dorsal osmoregulatory canals thin, 1.5-2.5 (1-3) wide, situated predominantly in same sagittal plane as the ventral canals. Ventral osmoregulatory canals, 40-60 (30-65) wide. Position of dorsal osmoregulatory canals not always constant; their loops may be situated laterally to the ventral canals. Genital pores unilateral, dextral. Genital ducts usually pass dorsally to longitudinal osmoregulatory canals, position of genital ducts between osmoregulatory canals within the same strobila appears rarely (for no more than $10 \%$ proglottides) (Fig. 5C, D). Development of proglottides gradual, 

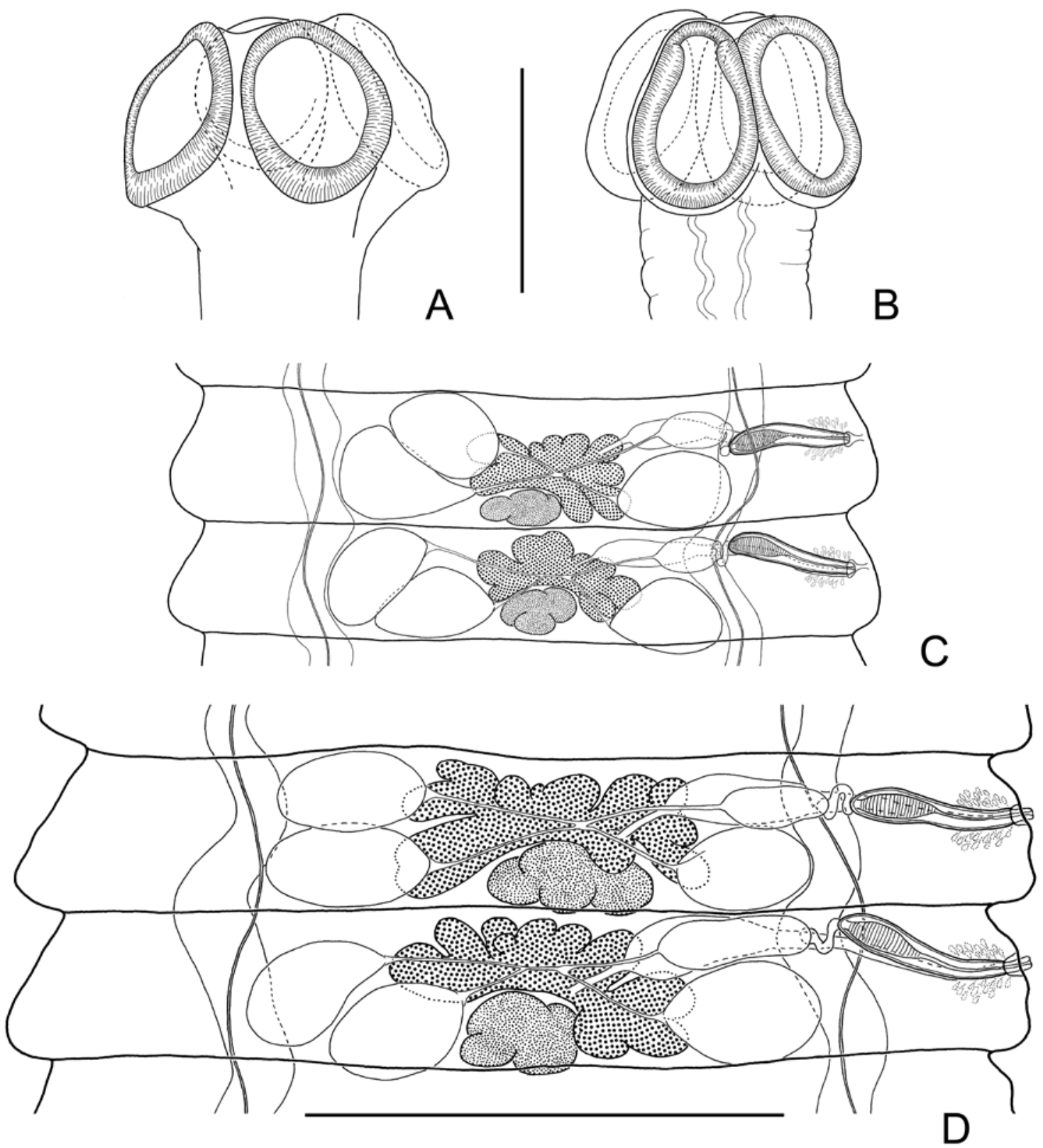

Fig. 5. Arostrilepis janickii sp. n. A-sublateral view of scolex (INVE 4196); B - dorso-ventral view of scolex (INVE 14774); C - holotype, male mature proglottides; $\mathbf{D}$ - holotype, hermaphroditic mature proglottides. Scale bars: A, B $=200 \mu \mathrm{m} ; \mathrm{C}, \mathrm{D}=500 \mu \mathrm{m}$.

protandrous. Strobilar part containing juvenile proglottides without external segmentation; proglottides become externally distinct at level of premature part of strobila.

Mature proglottides 150-185 × 920-1060 (90-200 × 670-1150), transversely elongate, trapeziform (Fig. 5C, D). Testes usually three in number, relatively large, of almost equal size, $113-155 \times 90-110(95-175 \times 50-115)$, oval or pear-shaped, commonly situated in triangle or rarely testes form one row (in no more than 50\% proglottides); poral testis separated from two antiporal testes by female gonads. Arrangement of testes varies within one individual. Cirrus-sac relatively short, 160-172 × 36-42 $(140-177 \times 31-42)$, with well-developed external mus- cular layers. Antiporal part of the cirrus-sac reaching the ventral longitudinal canal, rarely overlapping or slightly crossing it (Figs. 5D, 6C). Genital atrium simple, cupshaped, deep, opens laterally about the middle of the lateral proglottis margin. Cirrus 62-71 × 15-17 (60-82 $\times$ 13-17), cylindrical, armed along its entire length with relatively large (up to 3.5-4.3 long) rosethorn-shaped spines (Fig. 6A). Internal seminal vesicle with circular musculature, ovoid, 70-87 × 33-35 (55-90 × 27-36), shorter than half of the cirrus-sac length (Figs. 5D, 6C). External seminal vesicle transversely elongate, $90-120 \times 35-54$ $(70-135 \times 32-65)$, clearly outlined from vas defferens, slightly smaller than seminal receptacle. 

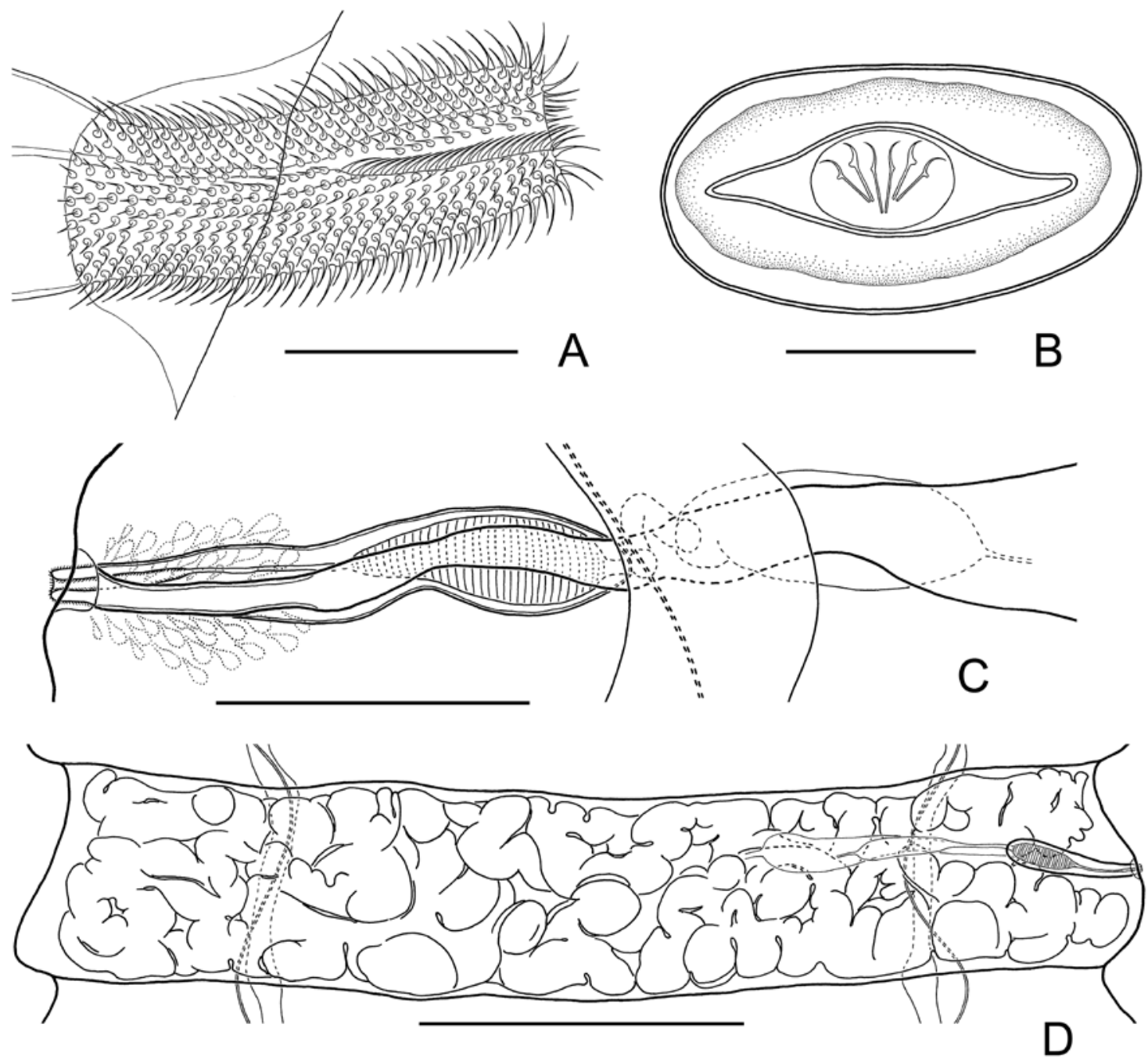

Fig. 6. Arostrilepis janickii sp. n. A-holotype, cirrus; B - egg (INVE 18513); C - holotype, copulatory part of vagina; D - holotype, gravid proglottis. Scale bars: A, B $=20 \mu \mathrm{m} ; \mathrm{C}=100 \mu \mathrm{m} ; \mathrm{D}=500 \mu \mathrm{m}$.

Ovary 260-317 (230-415) wide, median, fan-shaped, irregularly lobed, ventral to male genital organs, occupying a substantial part of median field, overlapping testes (Fig. 5D). Vitellarium 70-80 × 130-180 (45-80 × 95185), postovarian, median, scarcely lobed. Vagina tubular, clearly distinct from seminal receptacle; ventral to cirrussac. Copulatory part of vagina $65-78 \times 10-18(68-85 \times$ 9-22), thick-walled, covered externally by a dense layer of small, intensely stained cells; proximal part of vagina infundibular (Fig. 6C). Conductive part of vagina 67-80 $\times 15-27(60-85 \times 15-31)$, thin-walled, vastly varying in diameter depending on degree of filling with sperm. Seminal receptacle relatively small, transversely elongate, $118-158 \times 50-65(87-162 \times 47-70)$.

Uterus appears as a complex of fine-walled anastomosing tubes of various length and diameters that is positioned ventrally to other organs. With the development of the proglottides, the tubular structures increase in width, and the uterus becomes labyrinthine. Uterus commonly passes dorsally to longitudinal osmoregulatory canals or dorsal osmoregulatory canals enclosed within uterine trabecula. Rarely, uterus situated between longitudinal osmoregulatory canals; intersegmental variation does not show any regularity. Testes remain in the postmature and pregravid proglottides; the cirrus-sac and vagina persist in the gravid proglottides. Gravid proglottides transversely elongate, $270-295 \times 1580-1745(240-415$ $\times 890-2000$ ). Fully-developed uterus with a labyrinthine aspect, occupying the entire median field and extending bilaterally beyond the longitudinal osmoregulatory canals (Fig. 6D). Uterus contains a large number of small eggs. Eggs $27-36 \times 43-52$, elliptic, with thin outer coat (Fig. 6B); oncosphere 10-11 × 14-15. Embryophore fusiform, with straight polar processes, 11-15 × 34-40. Embryonic hooks small, 6.5-7.7 long. 

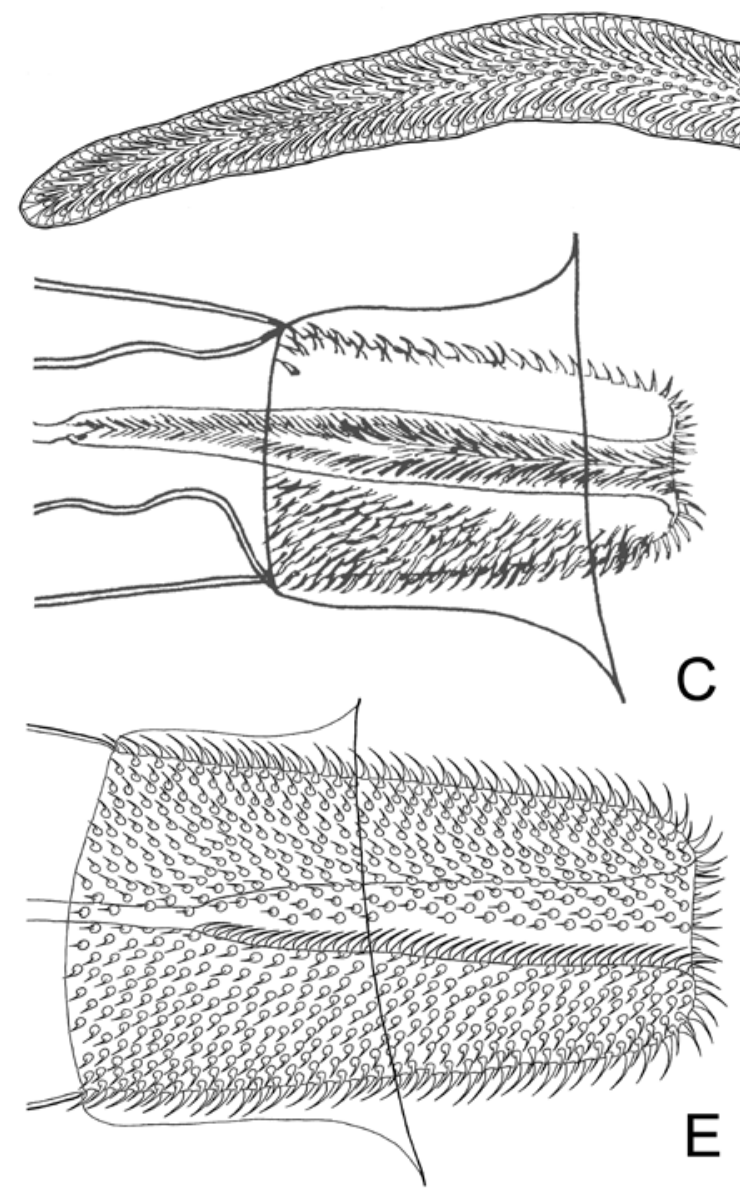

A
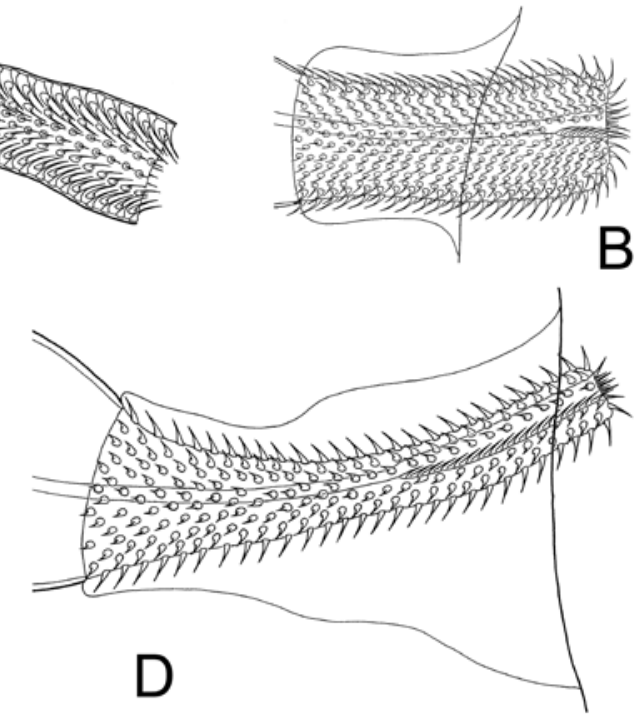

B

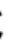

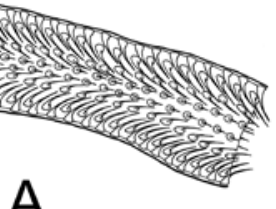

列
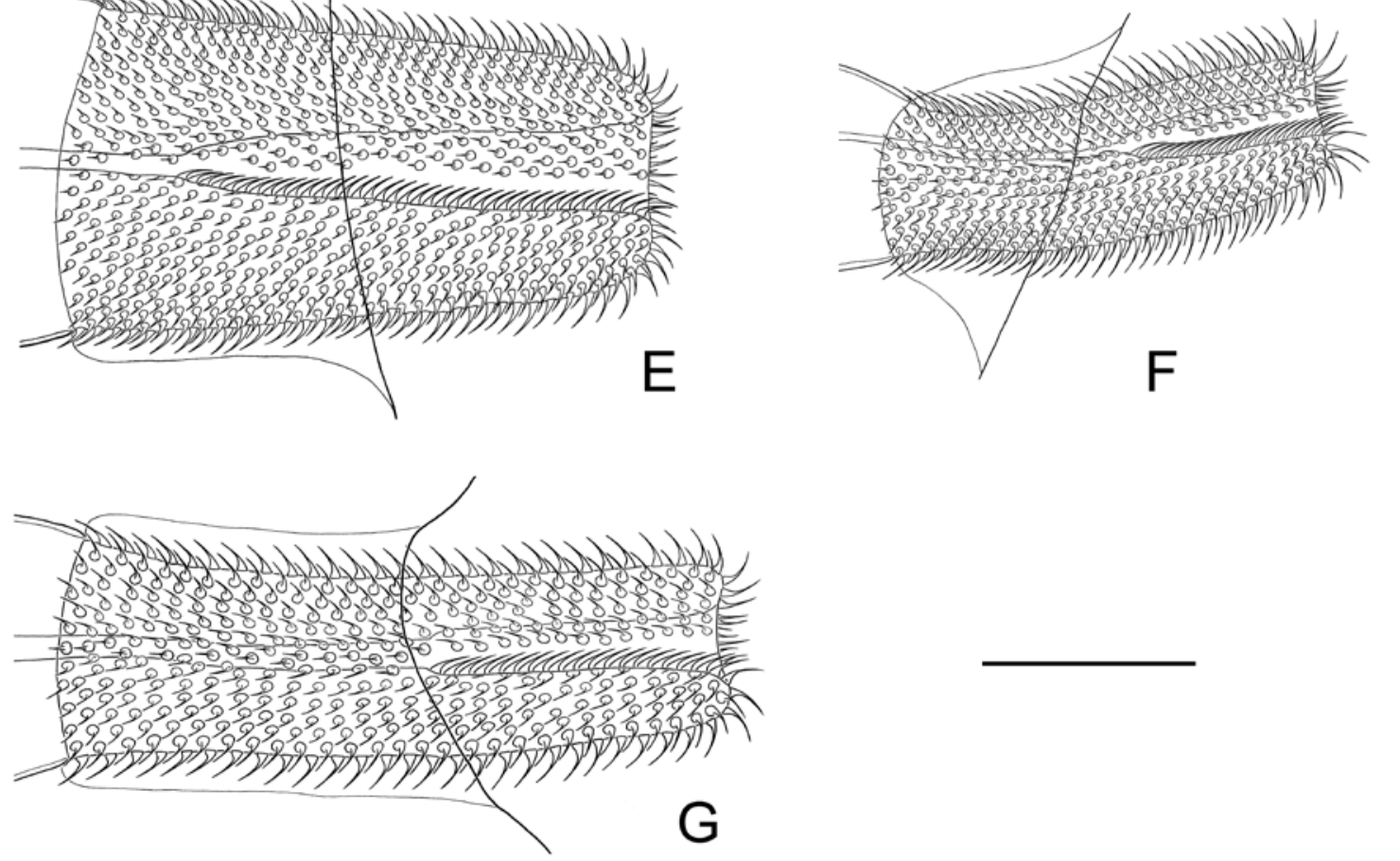

Fig. 7. Cirri of Arostrilepis spp. A-A. horrida; B - A. beringiensis; C-A. microtis; D - A. tenuicirrosa; $\mathbf{E}-A$. macrocirrosa; $\mathbf{F}-A$. janickii sp. n.; $\mathbf{G}-A$. intermedia sp. n. Scale bar: $20 \mu \mathrm{m}$. (C after Gulyaev and Chechulin 1997; A, D, E after Makarikov et al. 2011).

Type host: Arvicola scherman (Shaw) (Rodentia: Cricetidae).

Othe r hosts: Arvicola amphibius (Linnaeus), syn.: Arvicola terrestris (Linnaeus); Microtus arvalis (Pallas); Microtus multiplex (Fatio), syn.: Pitymys druentius (Miller); Chionomys nivalis (Martins); Microtus oeconomus Pallas.

Type loc ality: Vessy, Geneva, Switzerland.

Other localities: (from the collection of MHNG INVE) Le Lieu, VD, Switzerland; Roche - d'Or, JU, Switzerland; L'Auberson, VD, Switzerland; Le Souillot, (Doubs) France; Col de Cayolle, France.
Type materia l: Holotype: MHNG INVE 4196, ex A. scherman, Vessy, Geneva, Switzerland. The holotype specimen and two other cestode specimens belonging to the same species were mounted on one slide. The middle specimen with fully developed strobila and without scolex was chosen as holotype. Paratypes: INVE 18513, ex A. amphibius, Le Lieu, VD, Switzerland, 22.10.1994 (3 slides); INVE 18499, ex A. amphibius, Le Lieu, VD, Switzerland, 22.10.1994 (2 slides); INVE 19291, ex A. amphibius, Le Lieu, VD, Switzerland, 22.10.1994; INVE 19300, ex A. amphibius, Le Lieu, VD, Switzerland, 22.10.1994; INVE 19308, ex A. amphib- 
Table 1. Comparison of measurements of Hymenolepis procera and Arostrilepis janickii sp. n. (measurements in micrometres except where otherwise stated).

\begin{tabular}{lcc}
\hline & H. procera $^{1}$ & A. janickii sp. $\mathrm{n}$. \\
\hline Strobila: length & $28-40 \mathrm{~mm}$ & $50-80 \mathrm{~mm}$ \\
Strobila: width & $1.2-2.0 \mathrm{~mm}$ & $1.0-2.0 \mathrm{~mm}$ \\
Scolex: width & 310 & $190-240$ \\
Testes: size & 180 & $95-175 \times 50-115$ \\
Cirrus-sac: size & 130 & $140-177 \times 31-42$ \\
Egg: size & 48 & $27-36 \times 43-52$ \\
Oncosphere: size & 17 & $10-11 \times 14-15$ \\
Embryophore: size & 30 & $11-15 \times 34-40$ \\
\hline
\end{tabular}

${ }^{1}$ Measurements from Janicki $(1904,1906)$.

ius, Le Lieu, VD, Switzerland, 22.10.1994; INVE 13866, ex A. amphibius, Roche - d'Or, JU, Switzerland 29.07.1976 (3 slides); INVE 14774, ex M. multiplex, Col de Cayolle, France (two specimens on one slide); INVE 14775, ex C. nivalis, Col de Cayolle, France; INVE 39073, ex M. arvalis, Le Souillot, (Doubs) France, 19.10.1992 (2 slides); INVE 14775, ex C. nivalis, Col de Cayolle, France; INVE 19662, ex A. amphibius, L'Auberson, VD, Switzerland, 19.10.1994. All paratypes are deposited in MHNG.

Ety mology: This species has been named in honour of Dr. Constantin Janicki, a famous Polish cestode researcher.

Remarks. Arostrilepis janickii is distinguished from A. horrida, A. macrocirrosa, A. microtis, A. tenuicirro$s a, A$. beringiensis and $A$. intermedia by the length and shape of the cirrus. In specimens of $A$. janickii the cirrus is smaller relative to those in $A$. horrida, A. macrocirrosa, A. microtis and A. intermedia but longer in comparison to A. beringiensis (Fig. 7). The cirrus is armed with relatively large rosethorn-shaped spines and has a cylindrical form; these features distinguish $A$. janickii from A. macrocirrosa (conical cirrus), A. microtis (cirrus with wide conical basal region and a cylindrical distal region) and $A$. tenuicirrosa (cirrus is armed with relatively small needle-shaped spines and has a conical basal region and a very narrow cylindrical distal region). Arostrilepis janickii is distinguished from congeners based on its exceptionally small scolex and suckers. The hermaphroditic mature proglottides are smaller than those of $A$. horrida, A. microtis and A. tenuicirrosa. The cirrus-sac is shorter than in A. horrida, A. macrocirrosa, A. microtis and A. intermedia but longer than in $A$. beringiensis. The testes are smaller relative to those in A. horrida, A. microtis and A. tenuicirrosa. The ovary is smaller than in A. horrida and A. microtis (see Table 2). The antiporal end of the cirrus-sac reaches the ventral longitudinal canal but rarely overlaps it. Furthermore, this species is characterised by the changeable arrangement of its testes; testes may be situated in a triangle or in one row in one individual. In addition, the gravid proglottides are transversely elongate and the polar processes of the embryophore are straight in A. janickii. This species is a specific parasite of voles of the genera Arvicola, Microtus and Chionomys.

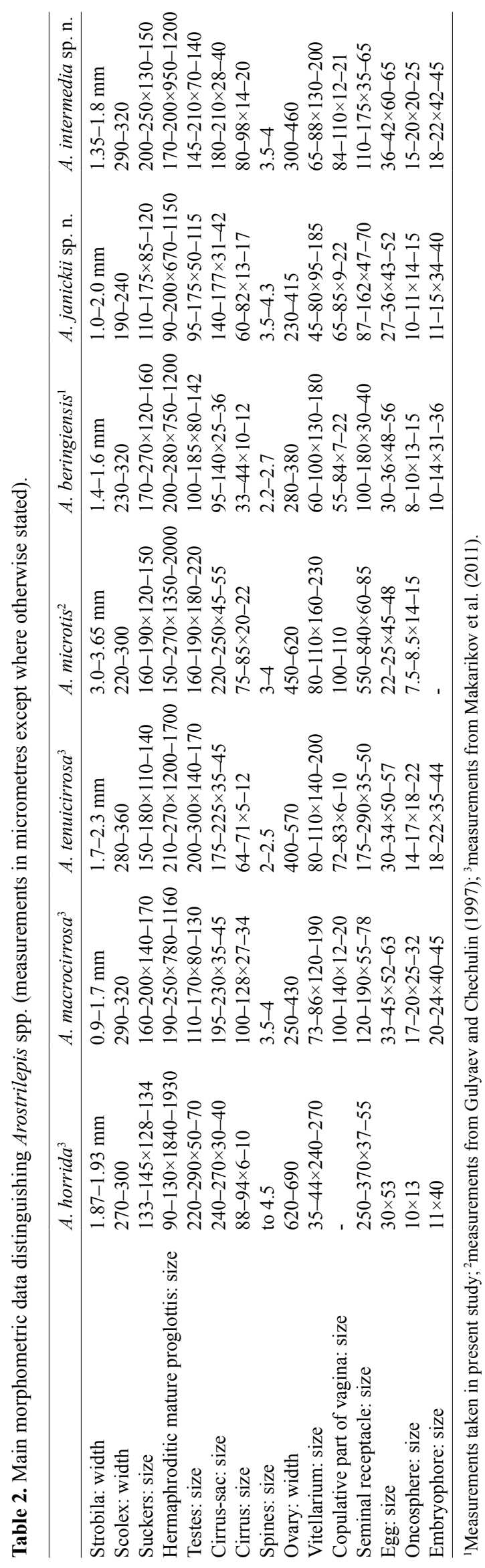




\section{DISCUSSION}

The type host of Arostrilepis beringiensis was identified as Lemmus sibiricus (Kerr) from the Chaun Lowland. At that time, L. sibiricus was considered to reside in all regions of Chukotka (Gromov et al. 1963). However, it was stated that L. sibiricus populations are restricted to habitats extending to the west of the Kolyma River. In contrast, the North American species Lemmus trimucronatus (Richardson) lives in the north and central parts of Chukotka to the east of the Kolyma River and occurs at the type locality for $A$. beringiensis (Gromov and Erbaeva 1995, Fedorov et al. 2003). Thus, L. trimucronatus is the true type host of $A$. beringiensis. Nevertheless, according to the present study, A. beringiensis also occurs in L. sibiricus and Myopus schisticolor (Lilljeborg) and appears to be a widespread parasite in lemmings.

Arostrilepis janickii has the same host associations and a similar geographic distribution relative to Hymenolepis procera Janicki, 1904 (Janicki 1904, 1906), which we consider to be a species inquirenda (Makarikov et al. 2011). Hymenolepis procera was described from Arvicola amphibius near the city of Basel, Switzerland, but the type specimens reported by Janicki $(1904,1906)$ could not be located in Polish collections. The inadequacy of the original description of $H$. procera makes it difficult to compare it with $A$. janickii or other species of the genus Arostrilepis. We can only note that $H$. procera is distinguished from $A$. janickii by its very short strobila (28-40 $\mathrm{mm}$ ), significantly smaller scolex width, shorter cirrussac length (130) and embryophore size (see Table 1). However, these characters are secondary in the systematics of Arostrilepis spp. Due to the lack of clear species limits, we do not consider $H$. procera as a valid species.

The main differentiating characters for species of Arostrilepis are the form and size of the cirrus, its armature and topography of the internal organs (i.e., type of arrangement of the testes and position of the cirrus-sac with regard to poral ventral osmoregulatory canals). As revealed by the present study, host specificity at generic level can be used as an additional criterion for distinguishing among the species. For example, A. microtis is a parasite of voles (Microtus and Arvicola), A. beringiensis is associated with lemmings (Lemmus and Myopus) and $A$. macrocirrosa and $A$. tenuicirrosa are specific parasites of red-backed voles (Myodes). The two new species described in present study are also specific parasites of different genera of the subfamily Microtinae. Based on current collections, Arostrilepis intermedia appears limited to red-backed voles, and A. janickii is a parasite of species of Arvicola, Microtus and Chionomys. Unfortu- nately, the identification of the type host of $A$. horrida is doubtful and it cannot be used for taxonomical conclusions (Makarikov et al. 2011).

Asakawa et al. (2002) reported A. horrida (s. 1.) from Eothenomys spp. This cestode differs from all known Arostrilepis species by a very short strobila $(30-40 \mathrm{~mm})$ and a significantly smaller cirrus-sac $(136-152 \times 25-33)$ and cirrus $(24-32 \times 3)$. Consistent with the recognition of $A$. horrida as a complex of species, we assume that this material may represent another species of the genus Arostrilepis.

Our series of descriptions including four new species of the genus Arostrilepis from voles from the Palaearctic Region demonstrates the tractability of morphological differentiation among what is now a rapidly expanding complex of cryptic species (Makarikov et al. 2011, present study). Further, our studies serve to corroborate recognition of the 10 distinct genetic lineages of Arostrilepis distributed among microtine rodents as delineated in Beringia (Hoberg et al. 2003, Cook et al. 2003). Ongoing research on this complex fauna is now exploring the identity and relationships of these lineages relative to morphological limits, host associations and geographic distributions in the Palaearctic and Nearctic (K.E. Galbreath, A. Makarikov, E.P. Hoberg, J.A. Cook; unpublished data).

Acknowledgements. We are grateful to Konstantin Feodorov, Vladimir Gulyaev, Nikolai Dokuchaev, Aleksandr Chechulin, Sergey Karpenko and Claude Vaucher for making cestode specimens from rodents from Asian part of Russia, Switzerland and France available for this study. Dr. Vladimir Gulyaev and Dr. Claude Vaucher made useful suggestions for the manuscript. Dr. Eric P. Hoberg kindly discussed results of ongoing work on microtine tapeworm faunas under the Beringian Coevolution Project and provided some editorial assistance on this paper. We wish to thank the curators of the cestode collections, Dr. Birger Neuhaus (Museum für Naturkunde, Berlin), Dr. Larisa Filimonova (Centre of Parasitology, A.N. Severtsov Institute of Ecology and Evolution, RAS, Moscow) and Dr. Jean Mariaux (Natural History Museum, Geneva, Switzerland). We also thank the staff of the Poronayskiy Reserve, who kindly helped in collecting materials. A substantial portion of the work was funded by the Russian Fund of Fundamental Research (grants 05-0449010, 08-04-00342 and 06-04-63137) and by the Lithuanian Science Council (grant MIP 118/2010). Postdoctoral fellowship of A.A. Makarikov is being funded by European Union Structural Funds project "Postdoctoral Fellowship Implementation in Lithuania" within the framework of the Measure for Enhancing Mobility of Scholars and Other Researchers and the Promotion of Student Research (VP1-3.1-ŠMM-01) of the Program of Human Resources Development Action Plan. Additional support for A.A. Makarikov was provided in part by the National Science Foundation (PBI grants DEB 0818696 and 0818823 ). 
Asakawa M., Tenora F., Koubkova B. 2002: Arostrilepis horrida (Linstow, 1901) (Cestoda: Hymenolepididae) from Eothenomys spp. (Rodentia) in Japan. Biogeography 4: 51-55.

Cook J.A., Hoberg E.P., Koehler A., Henttonen H., Wickström L., Haukisalmi V., Galbreath K., Chernyavski F., Dokuchaev N., Lazuhtkin A., MacDonald S.O., Hope A., Waltari E., Runck A., Veitch A., Popko R., Jenkins E., Kutz S., ECKERLiN R. 2005: Beringia: Intercontinental exchange and diversification of high latitude mammals and their parasites during Pliocene and Quaternary. Mamm. Study 30: 33-44.

Czaplinski B., Vaucher C. 1994: Family Hymenolepididae Ariola, 1899. In: L.F. Khalil, A. Jones and R.A. Bray (Eds.), Keys to the Cestode Parasites of Vertebrates. CAB International, Wallingford, UK, pp. 595-663.

EgOROVA T.P., NADTOCHII E.V. 1975: [Helminths of some rodents of the Kolyma Mountains.] In: Gel'mintologicheskie Issledovaniya Zhivotnykh i Rastenii. (Trudy Biologo-Pochvennogo Instituta AN SSSR). Vol. 26, pp. 33-44. (In Russian.)

Fedorov V.B., Goropashnaya A.V., Jahrola M., Cook J.A. 2003: Phylogeography of lemmings (Lemmus): no evidence for postglacial colonization of Arctic from the Beringian refugium. Mol. Ecol. 12: 725-731.

Genov T. 1984: [Helminths of insectivores and rodents in Bulgaria.] Izdatelstvo na Bulgarskata akademiya na naukite, Sofia, 348 pp. (In Bulgarian.)

Gromov I.M., Gureev A.A., Novikov G.A., Sokolov I.I., Strelkov P.P., ChAPSKi K.K. 1963: [Mammal fauna of the USSR.] Izdatel'stvo AN SSSR, Moskva, Leningrad, P. 1, 639 pp. (In Russian.)

Gromov I.M., Erbaeva M.A. 1995: [The mammals of Russia and adjacent territories. Lagomorphs and rodents.] Zool. Inst. RAN, St. Petersburg, 522 pp. (In Russian.)

Gulyaev V.D., Chechulin A.I. 1997: Arostrilepis microtis n. sp. (Cyclophyllidea: Hymenolepididae), a new cestode species from Siberian rodents. Res. Rev. Parasitol. 57: 103-107.

Haukisalmi V., Hardman L.M., Foronda P., Feliu C., Laakkonen J., Niemimaa J., Lehtonen J.T., Henttonen H. 2010: Systematic relationships of hymenolepidid cestodes of rodents and shrews inferred from sequences of $28 \mathrm{~S}$ ribosomal RNA. Zool. Scr. 39: 631-641.

Haukisalmi V., Henttonen H., Hardman L.M., Hardman M., Laakkonen J., Murueva G., Niemimaa J., Shulunov S., VaPALAhti O. 2009: Review of tapeworms of rodents in the Republic of Buryatia, with emphasis on anoplocephalid cestodes. ZooKeys. 8: 1-18.

Hoberg E.P., Kutz S.J., Galbreath K.E., Cook J.A. 2003: Arctic biodiversity: from discovery to faunal baselines - revealing the history of a dynamic ecosystem. J. Parasitol. 89: 84-95.

Hwang Y.T., Gardner S.L., Millar J.S. 2007: Hymenolepis horrida (Cestoda: Hymenolepididae) and Catenotaenia peromysci

Received 25 April 2011
(Cestoda: Anoplocephalidae) in voles from the Canadian Rockies. Comp. Parasitol. 74: 160-163.

JANICKI C. 1904: Zur Kenntnis einiger Säugetiercestoden. Zool. Anz. 27(25): 770-782.

JANICKI C. 1906: Studien an Säugetiercestoden. Z. Wiss. Zool. 81: 505-597.

Johri G.N. 1956: On a new cestode from the palm squirrel, $F u$ nambulus palmarum Linn. Proc. Natl. Acad. Sci. Allahabad 26 (series B): 274-277.

Kontrimavichus V.L., Smirnova L.V. 1991: [Hymenolepis beringiensis sp. $\mathrm{n}$. from the Siberian lemming (Lemmus sibiricus Kerr) and the problem of the sibling species in helminthology.] In G.P. Krasnoshchekov et al. (Eds.), Evoljucia parazitov (Materialy I Vsesojuznogo simpoziuma). Tol'yatti, Akademiya Nauk SSSR, pp. 90-104. (In Russian.)

Linstow O. 1901: Taenia horrida, Tetrabothrium macrocephalum und Heterakis distans. Arch. Naturgesch. (Berl.) 67 (1): 1-10.

Makarikov A.A., Gulyaev V.D., Kontrimavichus V.L. 2011: A redescription of Arostrilepis horrida (Linstow, 1901) and descriptions of two new species from Palaearctic microtine rodents, Arostrilepis macrocirrosa sp. n. and A. tenuicirrosa sp. n. (Cestoda: Hymenolepididae). Folia Parasitol. 58: 108-120.

Mas-Coma S., Tenora F. 1997: Proposal of Arostrilepis n. gen. (Cestoda: Hymenolepidae). Res. Rev. Parasitol. 57: 93-101.

Mas-Coma S., Tenora F., Gallego J. 1980: Consideraciones sobre los Hymenolepídidos inermes de Roedores, con especial referencia a la problemática entorno a Hymenolepis diminuta. Circular Farmacéutica. Barcelona, 38 (267): 137-152.

Murai E., Tenora F. 1973: Hymenolepis horrida (Linstow, 1901) from Microtinae in Hungary. Parasitol. Hung. 6: 111-116.

Rausch R. 1952: Studies on the helminth fauna of Alaska. XI. Helminth parasites of microtine rodents - taxonomic considerations. J. Parasitol. 38: 415-444.

Ryzhikov K.M., Gvozdev E.V. Tokobaev M.M., Shaldybin L.S., Matzaberidze G.V., Merkusheva I.V., Nadtochi E.V., Khohlova I.G., Sharpilo L.D. 1978: [Keys to the helminths of the rodent fauna of the USSR. Cestodes and trematodes.] Izdatel'stvo Nauka, Moskva, 232 pp. (In Russian.)

Schiller E.L. 1952: Studies on the helminth fauna of Alaska. X. Morphological variation in Hymenolepis horrida (von Linstow, 1901) (Cestoda: Hymenolepididae). J. Parasitol. 38: 554-568.

Skrjabin K.I., Matevosyan E.M. 1948: [Hymenolepidids of mammals.] Tr. Gel'mintol. Lab. 1: 15-92. (In Russian.)

Spassky A.A. 1954: [Classification of hymenolepidids of mammals.] Tr. Gel'mintol. Lab. 7: 120-134. (In Russian.)

Voge M. 1952: Variation in some unarmed Hymenolepididae (Cestoda) from rodents. Univ. Calif. Publ. Zool. 57: 1-52.

ŻARNOWSKI E. 1955: [Parasitic worms of forest small mammals (Rodentia and Insectivora) near Pulawy (Lublin). I. Cestoda.] Acta Parasitol. Pol. 3: 279-368. (In Polish.) 